\title{
Aqueous Systems of Dissolved Oxygen in Reservoir
}

\author{
$R$ Liqoarobby $^{1}$, Sunardi ${ }^{1,2}, Y$ Suparman $^{2}, K$ Fadilah $^{3}$ \\ ${ }^{1}$ Postgraduate Program of Environmental Studies, Universitas Padjadjaran, Jl. Dipatiukur No. 35 Bandung 40132, Bandung, West \\ Java, Indonesia \\ ${ }^{2}$ Faculty of Math and Sciences, Universitas Padjadjaran, Jl. Raya Bandung Sumedang KM 21 Jatinangor, Sumedang, West Java, \\ Indonesia \\ ${ }^{3}$ Center of Environmental and Sustainibility Sciences, Universitas Padjadjaran, Jl. Sekeloa Selatan 1, Bandung 40132, West Java, \\ Indonesia
}

\begin{abstract}
Oxygen plays a crucial role in aquatic ecosystem particularly for supporting aquaculture and hydropower. In freshwater, importance of oxygen is for metabolic respiration and balance for heterotrophic organisms. Oxygen is also involved in various chemical equations in which compounds influence each other. To prevent oxygen depletion, understanding the changes in DO and all interactions with other water qualities been reviewed with purposed to know aqueous systems work. Photosynthesis by phytoplankton is the main production of dissolved oxygen. Carbon dioxide as output from respiration of microorganisms and degradation of organic inputs and light as energy transformation of photosynthesis is needed in the process. The temperature level is involved as a determinant of gas solubility. There is also gas exchange from atmosphere to water as oxygen diffusion that move toward an equilibrium. However, dissolved oxygen absorption occurs in high demand in case an oxidizer in the degradation of organic matter which come into the reservoir. In eutrophic condition, the abundance of phytoplankton also requires oxygen for respiration, especially at night. The consumption of dissolved oxygen often spurs reservoir managers to monitor the input into the reservoir to build an aerator as a form of ensuring adequate dissolved oxygen circulation.
\end{abstract}

\section{Introduction}

Oxygen plays an important role for life, including in water. Water quality that is often used as a reference for a water's health is dissolved oxygen (DO). In freshwater, importance of oxygen is for metabolic respiration and balance for heterotrophic organisms. Environmental problems such as the influence of industrial and anthropogenic wastewater that affect aquatic organisms can cause fish paralysis. Fish's brain is not supplied with oxygen and death due to lack of oxygen (anoxia) in which the fish's body tissue cannot bind oxygen dissolved in the blood [1]. Oxygen is also involved in various chemical equations in which compounds influence each other. That are problems occur because oxygen depletion.

The corrosive water conditions are caused by chemical processes without oxygen that occur in the water, thus shortening the life of the installation machine. According to [2] the corrosivity of Cirata Reservoir is classified as high with the Langelier Saturation Index (LSI) between -0.21 to -1.08 for rivers around the reservoir is even worse once accumulated in the reservoir with an LSI of around -0.52 to. -1.49 . The problem of fish mortality also often haunts KJA farmers in the Cirata Reservoir which already in eutrophic condition [3]. This case is thought to stem from the depletion of oxygen in all layers of the water.

If oxygen levels are low, it will not only disrupt the balance of the reservoir ecosystem, but the process of decomposition of organic matter from aerobes to anaerobes, which causes toxic gases and is harmful to fish life and other activities. As a key parameter determining whether the water quality is good or not, understanding the changes in DO, is important information in the overall assessment of reservoir equilibrium. Environmental movement of contaminants and describing the subtle ecological changes is needed to be presence. Therefore, this paper interest to frame the specific interactions that take place with dissolved oxygen and its relationship with other water qualities.

\section{Literature review}

Aquatic ecosystems have mechanisms that control balance for all elements. Important things in water, oxygen is dissolved by diffusion and photosynthesis. Oxygen diffusion can come from physical process the atmosphere (reaeration) or oxygen in other zones. The diffusion process moved to achieve oxygen equilibrium. Oxygen on the surface can provide its dissolved oxygen (DO) levels into the water column. So, there is a causative of DO from surface to column depth which called diffusion.

Together with flux from the air, photosynthesis as primary production maintains a near saturation of $\mathrm{O}_{2}[4]$. Photosynthesis is carried out by phytoplankton with energy from sunlight converting $\mathrm{C}$ elements into organic $\mathrm{C}$ and oxygen. To find out how much DO results from the photosynthesis process, information on the number 
of individual phytoplankton and levels of carbon dioxide as $\mathrm{C}$ elements is needed. The ability of phytoplankton to produce oxygen by photosynthesis with consideration that phytoplankton also need oxygen for respiration. Therefore, another term should be added to reflect flow of oxygen to or from a system caused by plant activity includes their respiration which consume oxygen too. Because there are two directions back and forth, the causative for DO and phytoplankton is nonrecursive systems.

The number of individual phytoplankton in reproducing water is also influenced by temperature and $\mathrm{pH}$. Phytoplankton can grow at temperatures in range $20-30^{\circ} \mathrm{C}$ and $\mathrm{pH}$ in $6.0-8.0$ [5]. But in the fact, the temperature and $\mathrm{pH}$ are sometimes more than $30^{\circ} \mathrm{C}$ and 8.0 so their effect is involved as a determinant of the number of individual phytoplankton. Note that there are directions between phytoplankton with temperature and $\mathrm{pH}$.

Each of macronutrients required for algal growth in some instances carbon, nitrogen, phosphorus which absorbed in a fixed stoichiometric ratio. Phytoplankton could get $\mathrm{C}$ elements from carbon dioxide, $\mathrm{N}$ elements from nitrates, while $\mathrm{P}$ elements from phosphates [6]. Equation 1 shows the overall stoichiometry of photosynthesis:

$$
\begin{gathered}
106 \mathrm{CO}_{2}+16 \mathrm{NO}_{3}{ }^{-}+\mathrm{HPO}_{4}{ }^{-}+122 \mathrm{H}_{2} \mathrm{O}+18 \mathrm{H}^{+}+\text {trace elements and energy } \\
\uparrow \downarrow \\
\mathrm{C}_{106} \mathrm{H}_{263} \mathrm{O}_{110} \mathrm{~N}_{16} \mathrm{P}_{1}+138 \mathrm{O}_{2}
\end{gathered}
$$

This stoichiometry operates in the forward direction, that is, $\mathrm{CO}_{2}, \mathrm{NO}_{3}$, and $\mathrm{PO}_{4}$ being converted to algal protoplasm and oxygen. Photosynthesis only proceeds during daylight hours [7]. As a gate, transparency will determine how much radiant energy could absorbed by phytoplankton producing oxygen. In this case, DO also depend on the transparency level of the water as physical structure of a waterbody.

The physical structure of a reservoir is determined by the distribution of light, heat, waves, currents and seasonal variations that could affects solubility gas. As a common physics parameter, temperature level is involved as a determinant of solubility, both for dissolved oxygen and carbon dioxide. If the lake is also biologically productive it will at times be supersaturated with $\mathrm{O}_{2}$ and $\mathrm{CO}_{2}$, so both of that are released.

Gaseous $\mathrm{CO}_{2}$ dissolves in a liquid phase and then dissociates into various dissolved species such as bicarbonate or ion carbonate. This dissociation depends on the $\mathrm{pH}$ of the liquid phase. $\mathrm{CO}_{2}$ concentration itself are from phytoplankton and zooplankton respiration especially in reservoir which is categorized in the eutrophic. Those all make complexity directions which influences one and others. Otherwise, zooplankton also eat phytoplankton for reproduction. Also be direction in aqueous systems.

In reservoir also has chemical structure that formed from the spread of chemical compounds. In natural nutrient cycles, the amount of oxygen consumed as an oxidizing agent in the nitrification process converts ammonia compounds into nitrites and then nitrates [8]. This process is aerobic in which the growth of the bacteria is in autotrophic conditions with an optimum temperature of $20-25^{\circ} \mathrm{C}$ and a $\mathrm{pH}$ between 7.5 to 8.5 .

$$
\begin{aligned}
& 2 \mathrm{NH}_{4}{ }^{+}+3 \mathrm{O}_{2}+2 \mathrm{OH}^{-}+\text {Nitrosomonas } \leftrightarrow 2 \mathrm{NO}_{2}^{-}+2 \mathrm{H}_{4}{ }^{+}+4 \mathrm{H}_{2} \mathrm{O}+59,4 \mathrm{Kcal} \\
& \mathrm{NO}_{2}{ }^{-}+1 / 2 \mathrm{O}_{2}+\text { Nitrobacter } \leftrightarrow \mathrm{NO}_{3}{ }^{-}+19 \mathrm{Kcal}
\end{aligned}
$$

Although the system is in an oxygenated state or based on equilibrium calculations predict that all of the elements should be in their most oxidized state, it is quite possible to find reduced species of elements in the system. The major complication associated with using redox parameters for predicting water quality effects is the inherent dynamic state of natural systems, that is, equilibrium is seldom achieved [7]. So, measurement of equilibrium in a system owing to the dynamic situation in natural systems, in which several ionic species can affect the measurement simultaneously. As the oxygen concentration in a system is lowered (as the system becomes anaerobic), bacteria start using oxygen bound in nitrate and the nitrogen is reduced from nitrate to nitrite as the oxygen is removed. Those systems are great importance in view of the frequent contamination of water by reduced species of nitrogen.

Microorganisms as biological structure in reservoir for decomposing organic waste with consuming dissolved oxygen. How much of the available DO is consumed by aerobic bacteria, robbing other aquatic organisms of the oxygen they need to live which called Biochemical Oxygen Demand (BOD) and Chemical Oxygen Demand (COD). BOD shows the ability of bacteria to degrade organic matter biologically which monitored from the use of oxygen for 5 days of titration. COD describes the amount of oxygen required to chemically oxidize organic matter, which can be degraded biologically (including BOD) or difficult to degrade biologically. For measure carbon in the organic form is reason BOD or COD analyses [7].

All interactions been reviewed with purposed to know aqueous systems work. Conceptual diagram is shown in Figure 1. The direction of the arrow indicates that the variable affects the variable it points to. In some cases, one arrow has two direction or called nonrecursive model because contains one or more 'feedback loops' or 'reciprocal' effects. 


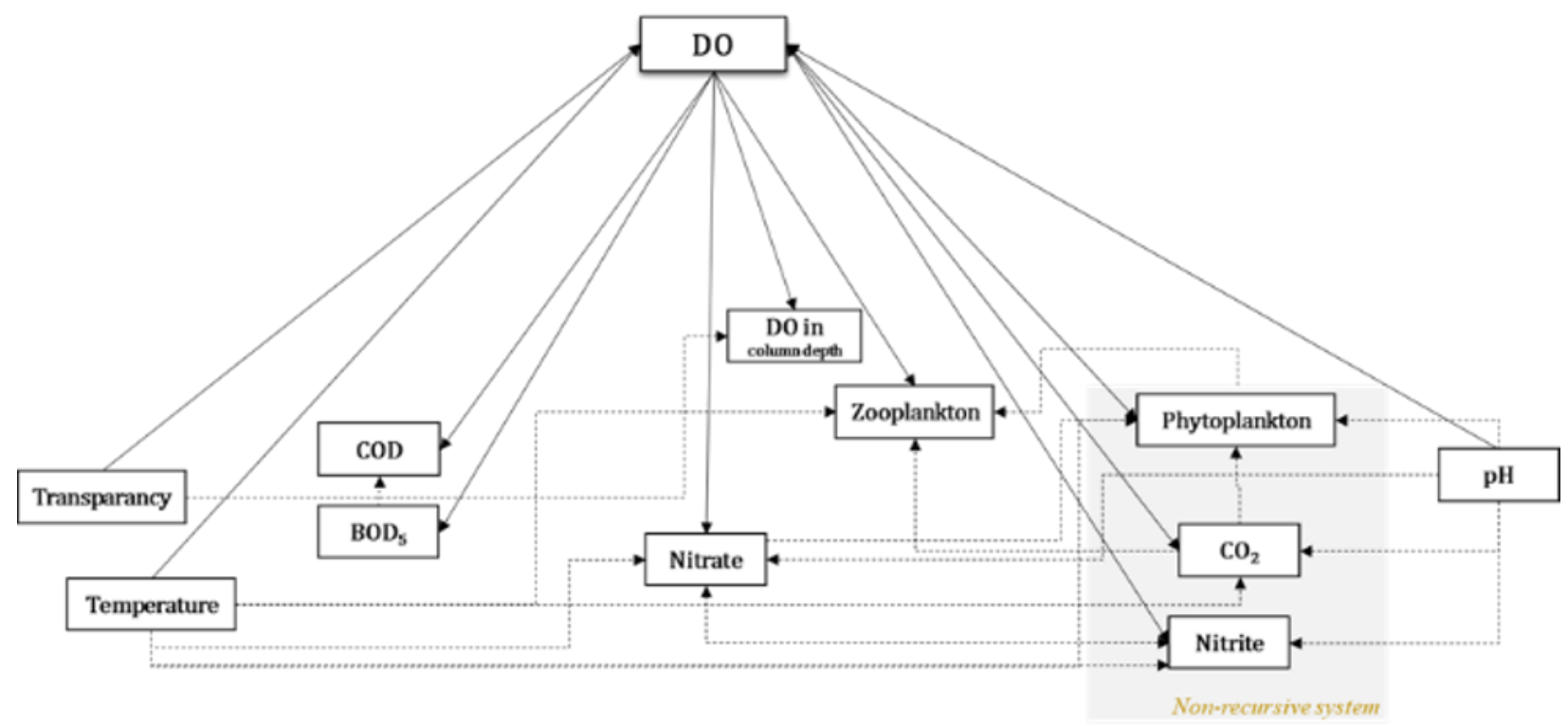

Fig 1. Conceptual Diagram Water Quality Interactions. The arrows mean causative agent to.

The relationship between DO and water quality parameters from the production and consumption of DO illustrates the reservoir ecosystem which is an integral set of abiotic (physics-chemical) and biotic components that interact in a complex manner, and form a functional system [9]. These physical, chemical and biological parameters then form a unique structure in each of these aquatic ecosystems.

According to [10] and all the explanations, the important roles of DO in waters are as follows:

1. The need for respiration by microorganisms,

2. The oxidation of organic and inorganic materials with the end result is nutrients which can ultimately provide fertility in waters, and

3. Reduction of chemical compounds to become simpler in the form of nutrients and gases so as to help reduce the pollution load on waters.

Oxidation-reduction potentials are useful measures of the oxidation state to which a particular element moves in a natural system. Oxygen is one of predominant elements involved in natural redox processes.

Overall, various measures have been carried out in order to ensure that the reservoir as a water resource is maintained and to restore the environmental carrying capacity to be more optimal. Factors that cause obstacles in managing water resources include stakeholders who ignore environmental needs, prefer personal interests, still rigid with administrative boundaries and community awareness around the watershed to conserve and protect water resources [11]. Over enriched with plant nutrients capable of causing environmental perturbations and then going to eutrophication. So, in eutrophic reservoir, water quality is usually significantly degraded. Importance of the catchment area to inputs to reservoirs and high demand for dissolved oxygen often spurs the stakeholder to monitor the reservoir or build an aerator to prevent dissolved oxygen depleting.

\section{Conclusions}

All interactions of water qualities been reviewed with purposed to know aqueous systems of work. Photosynthetic activity as the main source of dissolved oxygen production will be related to the number of individual phytoplankton, transparency level and carbon dioxide levels in the waters. However, the high demand for dissolved oxygen in various activities in the reservoir ecosystem. Its role as an oxidizer for nitrification and absorption by microorganisms such as phytoplankton and zooplankton for respiration can reduce oxygen levels to depletion. The level of oxygen demand in the degradation of organic matter is represented in the values of BOD and COD. Aquatic ecosystems have mechanisms that control balance for all elements. Important things in water, oxygen is dissolved by diffusion and photosynthesis

\section{Acknowledgement}

Best thankful for Center for Environmental and Sustainability Sciences, Padjadjaran University. This paper intended the requirements for a master's degree in Environmental Sciences, Postgraduate School, Padjadjaran University.

Figures and tables, as originals of good quality and well contrasted, are to be in their final form, ready for reproduction, pasted in the appropriate place in the text. Try to ensure that the size of the text in your figures is approximately the same size as the main text (10 point). Try to ensure that lines are no thinner than 0.25 point.

\section{References}

1. Jones, H.R.E, Fish and River Pollution. Buther Worth. London : 203 (1964) 
2. Sunardi, S. M. Ariyanti, M. Agustian, S.

Withaningsih, Parikesit, H. Juahir, A. Ismail dan O. S. Abdoellah, Water corrosivity of polluted reservoir and hydropower sustainability. Scientific Reports Natureresearch (2020)

3. Pratiwi, N; S. Hariyadi; N. Soegesty; dan D. Y. Wulandari, Penentuan Status Trofik Melalui Beberapa Pendekatan (Studi Kasus: Waduk Cirata), Jurnal Biologi Indonesia 16(1): 89-98 (2020)

4. Shapley, Chemistry 102 : Dissolved Oxygen and Carbon Dioxide. University of Illinois at UrbanaChampaign (2011)

5. Wetzel, Robert, G., Limnology Lake and River Ecosystems, Academic Press (2001)

6. Widayat, Wahyu. Suprihatin, and A. Herlambang. Biofiltrasi Menggunakan Media Plastik Tipe Sarang Tawon. JAI Vol 6. No. 1 (2010)

7. Waite, Thomas., Principles Water Quality. Academic Press (1984)

8. Effendi, Hefni., Telaah Kualitas Air, Kanisius (2003)

9. Kusmeri, L., \& Rosanti, D., Struktur Komunitas Zooplankton di Danau Opi Jakabaring Palembang, Sainsmatika, 12(1), 8-20 (2015)

10. Salmin, Oksigen Terlarut (DO) Dan Kebutuhan Oksigen Biologi (BOD) Sebagai Salah Satu Indikator Untuk Menentukan Kualitas Perairan Oseana, Volume XXX, Nomor 3: 21 - 26 (2005)

11. Septiadi, Frida, Model Pencemaran Logam Berat Dengan Pengembangan Single Lake Modelling (Studi Kasus Waduk Cirata, Jawa Barat), Tesis. Magister Ilmu Lingkungan, Universitas Padjadjaran (2013) 